\title{
Removal Processes for Tributyltin During Municipal Wastewater Treatment.
}

\author{
M.D. Scrimshaw ${ }^{a^{*}}$, D. Hala ${ }^{a}$, A.E. Okiemute ${ }^{a}$, E. Cartmell ${ }^{b}$ and J.N. Lester ${ }^{b}$

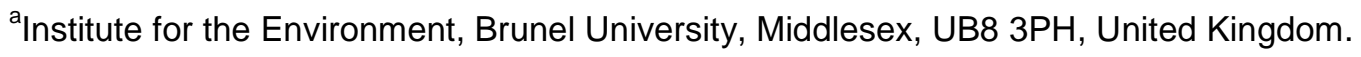 \\ ${ }^{\mathrm{b}}$ Cranfield Water Science Institute, School of Applied Sciences, Cranfield University, Bedfordshire, MK43 \\ OAL, United Kingdom. \\ Corresponding author mark.scrimshaw@brunel.ac.uk, Tel +44 (0) 1895 267299, Fax +44 (0) 1985 .
}

\section{Abstract}

The fate and behaviour of tributyltin at two wastewater treatment works was examined. Both sites had two inlet streams, and each utilised high rate biological filters (biofilters) on one the streams, before treatment of the combined flows on trickling filters, with one having additional tertiary processes, installed to remove ammonia and solids. The study was designed to determine if these processes enhanced the removal of tributyltin. Degradation of TBT was observed in one of the biofilters, possibly as a result of temperature and hydraulic loading.

At the treatment works with tertiary processes the mass flux showed the overall removal of tributyltin was $68 \%$, predominantly due to removal with solids in the primary settlement processes. However, overall removal of $95 \%$ was observed in the conventional trickling filter works with $94 \%$ of this due to biodegradation in the trickling filter. The two works both removed tributyltin, but at different treatment stages and by different processes. Differences in the form (solubility) of tributyltin in the influent may have attributed to this, although further understanding of factors controlling degradation would allow for a more complete assessment of the potential of biological processes to remove hazardous compounds from wastewaters.

Keywords trickling filter; tributyltin; removal; biodegradation; wastewater 


\section{Introduction}

The fate, behaviour and environmental impact of tributyltin (TBT) in the aquatic environment as the result of its use as an antifoulant on the hulls of boats and ships is well understood (Clarke et al. 1998; Dowson et al. 1993a). Restrictions on the use of TBT as an antifoulant, including a retail ban in the United Kingdom (UK) on the sale of TBT containing antifoulant paints for use on vessels $<10 \mathrm{~m}$, brought about a dramatic reduction in its presence in estuarine and coastal waters (Dowson et al. 1993b; 1993c; 1994). With this there was a concomitant reduction in its endocrine disrupting impact in particular for molluscs including the economically important oyster (Dowson et al. 1993c). Although endocrine disruption in the environment had been recognized since the 1930's (Dodds et al. 1938) the environmental damage caused by TBT's use as a ship antifoulant brought this problem to the attention of a wide audience (Alzieu et al. 1989)

Whilst the cessation of the use of TBT as an antifoulant on small vessels brought about dramatic reductions in the concentrations of TBT detected in inland and coastal waters it did not completely eliminate it. Treated sewage effluent still continued to contain TBT as the result of other industrial applications, as a plasticizer, wood preservative, agrochemical, materials and textiles processing, household products and food stuff packaging (Hoch 2001). These applications lead to TBT or its metabolites dibutyltin (DBT) and monobutyltin (MBT) being discharged to sewer from both domestic and industrial sources. Thus wastewater treatment works (WWTWs) become important points in determining and controlling the discharge of TBT compounds to the aquatic environment as they are for other hazardous substances and emerging pollutants (Bedding et al. 1982; Plagellat et al. 2004; Jones et al. 2007a). There are a limited number of detailed studies of the fate and behaviour of TBT and its breakdown products DBT and MBT in WWTWs and include those by Fent and Muller (1991) and Voulvoulis et al. (2004).The study by Fent and Muller (1991) was undertaken at Zurich WWTWs, where treatment included primary clarification, activated sludge treatment and tertiary 
treatment by sand filtration. A comparable works was studied by Voulvoulis et al. (2004). Here primary treatment was achieved by lamella separators and secondary treatment was via activated sludge using sequencing batch reactors (SBR). There was however, no tertiary treatment. Both studies concluded that TBT removal was strongly dependent on association with suspended solids and the efficiency of suspended solids removal. As a result Fent and Muller (1991) concluded that TBT was efficiently removed mainly by sedimentation in the primary clarifier. From the study in the United Kingdom, Voulvoulis et al. (2004) drew similar conclusions, noting the close correlation between suspended solids removal and TBT removal and attributing this to its affinity for solids due to its lipophillic nature. Given the concentrations of TBT in both primary sludge and waste activated sludge (WAS), they concluded that adsorption was the paramount process in their removal. Neither group of researchers totally discounted biodegradation. Fent and Muller (1991) suggest it may have a limited role but due to the high solids concentrations in sewage very little of TBT is in the soluble phase and hence available to bacteria for metabolism, a situation they point out which is completely different to seawater where solids are much lower, hence TBT and its breakdown products are relatively more soluble and aerobic breakdown does occur (Maguire 1987; Seligman et al. 1986, 1989). This study was undertaken to further elaborate on the fate and behaviour of TBT during conventional wastewater treatment at two WWTWs. In particular, the fate of TBT in trickling (biological) filters was determined, to access the contribution of adsorption and biodegradation to removal.

\section{Materials and Methods}

\subsection{Site Descriptions}


Two sites were included in the study, both were trickling filter biological treatment processes, and in addition, at one site (described as the tertiary treatment works) further treatment processes for the removal of ammonia and suspended solids.

The tertiary treatment works received an average flow of $59 \mathrm{Ml} \mathrm{d}^{-1}$ with an approximate equal split (depending on specific flow conditions) between two influent streams, from 'high level' and 'low level' sewers (Figure 1). The sewage entering from the 'high level' inlet comprised mainly municipal wastewater with a hospital discharge comprising $<1 \%$ of the flow. Sewage from the 'low level’ inlet again comprised mainly municipal wastewater with trade effluent varying from 5$10 \%$ depending on flow conditions. Both 'low level' and 'high level' crude sewage underwent separate primary settlement processes. In addition the 'low level' crude sewage following primary sedimentation underwent high-rate biological treatment in biotowers the effluent from which underwent further settlement. The settled biotower effluent was subsequently combined with the 'high level' settled sewage to provide the influent to the trickling filters (TF) where it was subjected to secondary biological treatment. Treatment processes which follow biological treatment are frequently termed "tertiary treatment" processes, and at this WWTW, two unit processes were present prior to final discharge. These were biological aerated flooded filters (BAFFs) and rapid gravity filtration (RGF), which we have referred to as a "tertiary process". The backwash from the BAFFs and RGF returned to the head of the works at the 'high level' sewer whilst the sludge liquor returns from the humus tanks, decant liquors from the sludge consolidation tanks and centrifuge returned to the head of the works at the 'low level' inlet. The conventional trickling filter treatment works received a flow of $75.8 \mathrm{Ml} \mathrm{d}^{-1}$ which was split between a crude influent, of predominantly municipal sewage $\left(71.3 \mathrm{Ml} \mathrm{d}^{-1}\right)$, and a crude sewage from a brewery $\left(4.5 \mathrm{Ml} \mathrm{d}^{-1}\right)$. The municipal crude influent underwent primary treatment whilst the brewery crude went straight to high rate biological filters before the flows were combined (as filter feed) prior to trickling filter treatment (Figure 2), from which humus sludge was returned to the head of the works for co-settlement. All sludges, including imports, were treated by gravity 
belt thickeners (GBT) and mesophilic digestion followed by dewatering in the plate press. Liquor from the GBT were returned to the head of the works, liquors from the plate press were combined with brewery crude sewage for treatment in the high rate biological filters.

\subsection{Sampling Strategy}

Sampling occurred in July 2007 and involved taking samples at four hour intervals for a duration of 96 hours over five working days at locations throughout the treatment process. This resulted in 25 samples from each location analysed individually, yielding $>500$ samples from the main wastewater flow streams. The humus sludge and return liquor were sampled once every $24 \mathrm{~h}$ for $96 \mathrm{~h}$. There were eight return/sludge streams for the tertiary treatment works, each sampled five times, yielding 40 samples. There were six return liquor sludge streams at the conventional trickling filter works which were each sampled five times yielding 30 samples.

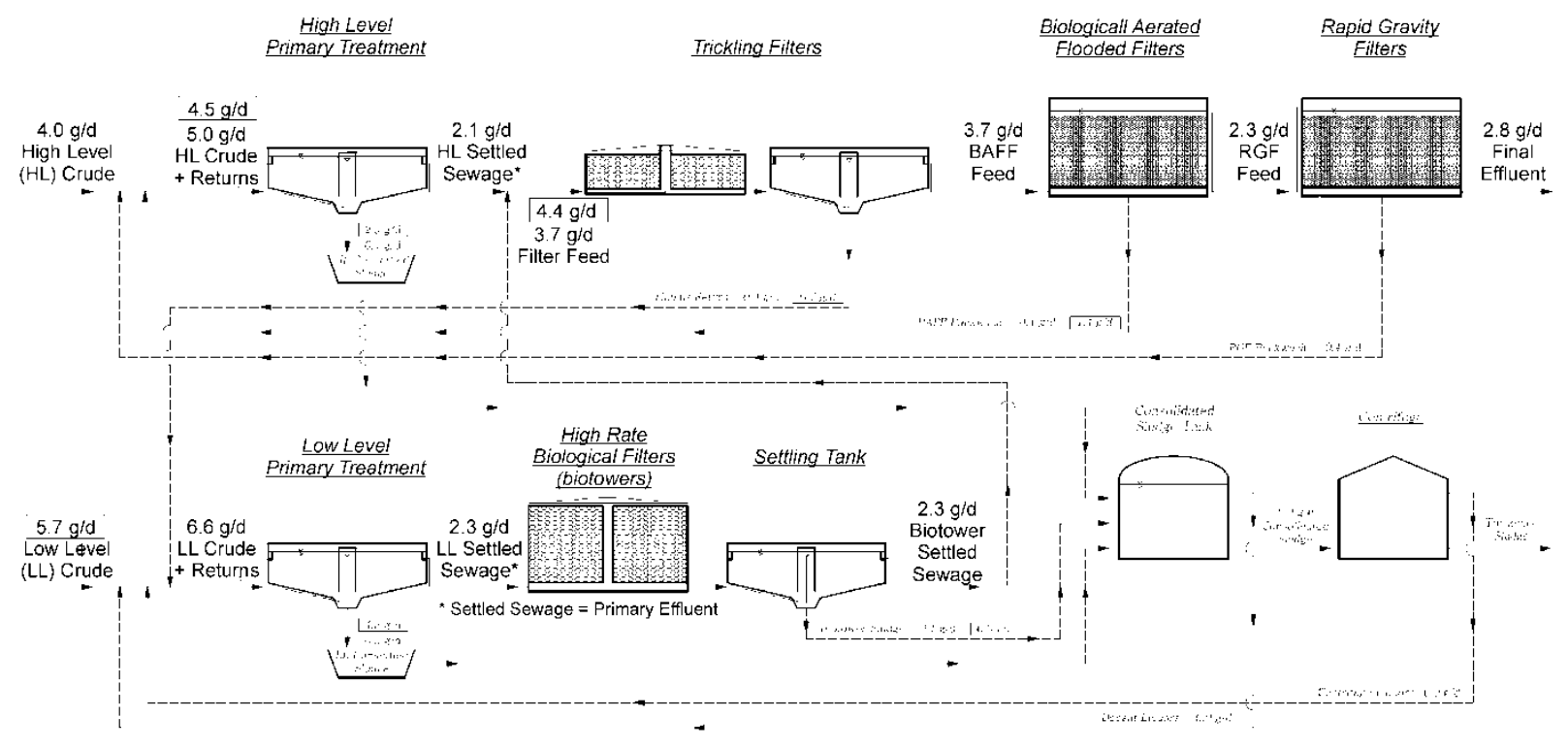

Figure 1. The mass flux of TBT through the tertiary treatment works. Main flows through works indicated by solid lines with sludge and return flows dashed lines and italic text. Values in boxes are calculated fluxes. 


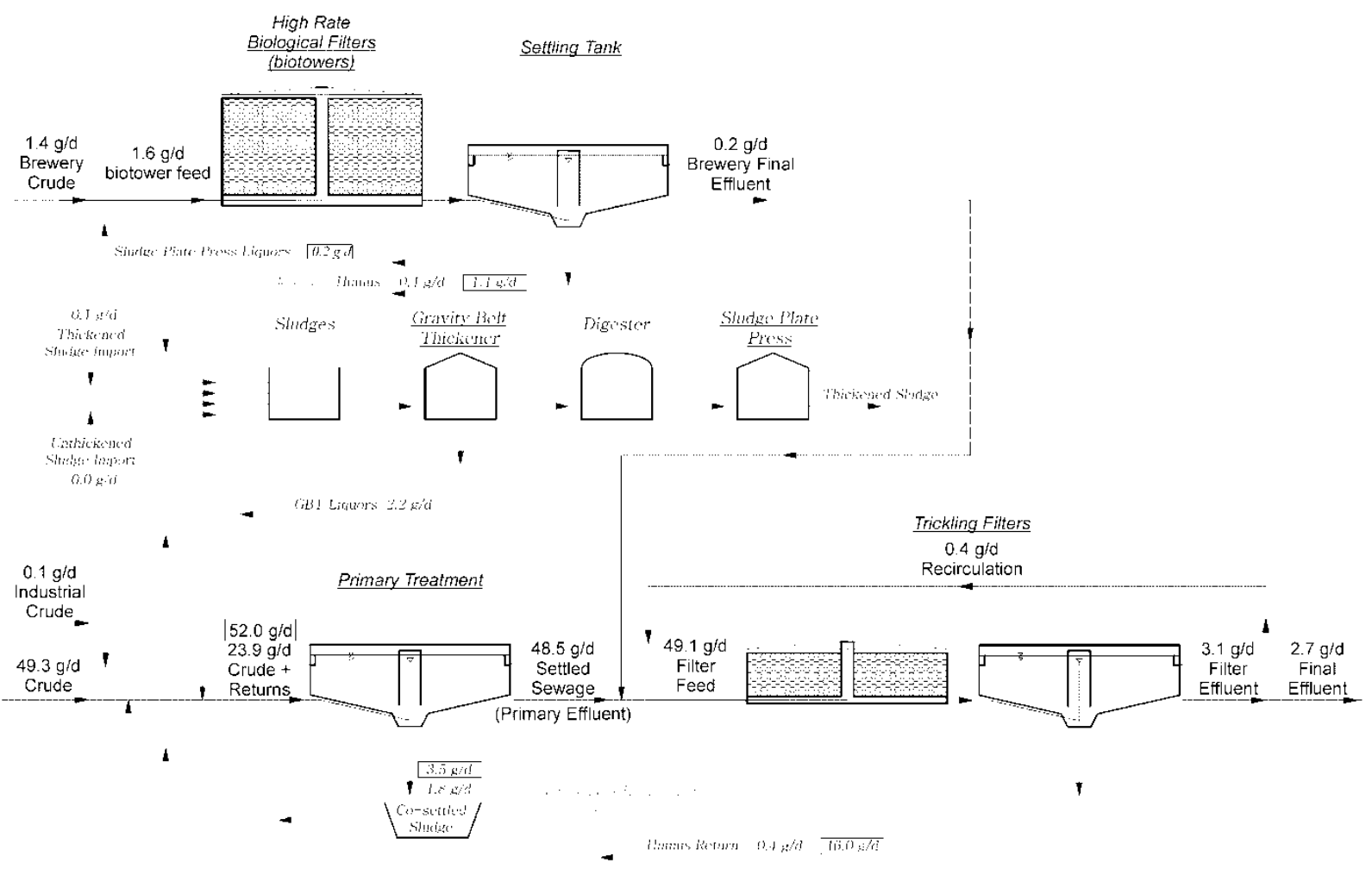

Figure 2. The flux of TBT through the conventional trickling filter treatment works. Main flows through works indicated by solid lines with sludge and return flows dashed lines and italic text. Values in boxes are calculated fluxes.

\subsection{Mass Balance Calculations}

The mass flux of TBT across the secondary treatment processes for both works was calculated by multiplying the flow velocities in $\left(\mathrm{I} \mathrm{d}^{-1}\right)$ by the TBT concentrations (in $\left.\mu \mathrm{g} \mathrm{I}^{-1}\right)$ within the particular process flow-stream based on the equation $\left(\sum \mathrm{flow}_{\mathrm{i}(1-25)} \times[\mathrm{TBT}]_{\mathrm{i}(1-25)}\right) / 25$ and equated to a TBT loading in $\mathrm{g} \mathrm{d}^{-1}$. The sludge mass flux was also calculated by multiplying the volume of the sludge returned per day $\left(\mathrm{m}^{3} \mathrm{~d}^{-1}\right)$ by the concentration of TBT $\left(\mu \mathrm{g} \mathrm{I}^{-1}\right)$ in the same manner and equated to a load in $\mathrm{g} \mathrm{d}^{-1}$. 


\subsection{Sample Preparation and Analysis}

Sewage and final effluent samples were analysed for total TBT by placing into $250 \mathrm{ml}$ Pyrex glass bottles (Fisher Scientific, Loughborough, UK) and acidified $(\mathrm{pH} \leq 2)$ with $2 \mathrm{ml}$ trace metal analysis grade hydrochloric acid (Fisher Scientific, Loughborough, UK). Subsequently, $0.5 \mathrm{ml}$ of 0.25\% tropolone (Sigma Aldrich, Poole, Dorset, UK) in methanol (Rathburns, Walkerburn, UK) were added prior to extraction onto either $3 \mathrm{ml}$ or $6 \mathrm{ml}$ octadecyl-modified silica solid phase extraction (SPE) cartridges (Macherey-Nagel, Düren, Germany). The SPE cartridges were conditioned with $2 \mathrm{ml}$ methanol (Rathburn, Walkerburn, UK) and $0.5 \mathrm{ml}$ of $1 \%$ tropolone (SigmaAldrich, Poole, Dorset, UK) in methanol (Rathburn, Walkerburn, UK) and a plug of glass wool was placed into each SPE tube in order to minimise cartridge obstruction by particulates. Once samples were extracted, the cartridges were dried under vacuum prior to storage at $-18^{\circ} \mathrm{C}$. Samples with high solids (sludges and return flows at the site) were transferred into a $50 \mathrm{ml}$ centrifuge tube with $2 \mathrm{ml}$ of concentrated trace metal analysis grade hydrochloric acid (Fisher Scientific, Loughborough, UK). All samples were then stored at $-18^{\circ} \mathrm{C}$ until analysis. The quantification of organotins involved either elution of the SPE cartridges or extraction of sludges, followed by derivatisation of the extracts with sodium tetraethylborate (Sigma-Aldrich, Poole, Dorset, UK) and extraction of the ethyl-derivatives into trimethyl pentane (Sigma-Aldrich, Poole, Dorset, UK) before quantification by gas chromatography with flame photometric detection using a Perkin-Elmer Clarus 500 system (Perkin-Elmer, Beaconsfield, UK) with a programmable split/splitless injector and autosampler as described in detail in Voulvoulis et al. (2004). Method detection limits were $0.044 \mu \mathrm{g} \mathrm{I}{ }^{-1}$ for samples within the wastewater flow

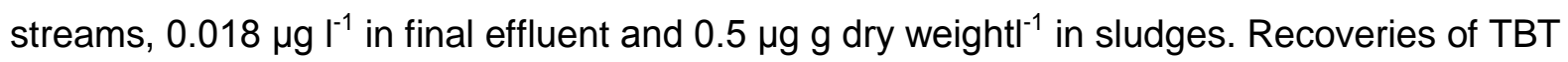
were from $77-85 \%$ in different sample types, with highest recoveries from the final effluent. 


\section{Results}

3.1 The Fate of Tributyltin in the Tertiary Treatment Works

\subsubsection{Tributyltin in the Crude Sewage}

There are two inlets to the tertiary treatment works, designated 'high level' and 'low level'. Concentrations of TBT in the 'high level' crude sewage, which contained no works return liquors at the crude sampling point, averaged $0.164 \mu \mathrm{gl}^{-1}$ (Table 1). A maximum input of TBT (1.108 $\mu \mathrm{g}$ $\mathrm{I}^{-1}$ ) in this 'high level' flow stream was observed on Monday at 22:00 (Figure 3a). A diurnal trend in the flows of the 'high level' crude was apparent, with lower flows occurring at 06:00 each day. However, there appeared to be no correlation of this trend with the concentration of TBT. The concentrations in the 'low level' crude (plus the humus and decant returns) were characterised by a higher average TBT concentration of $0.211 \mu \mathrm{gl}^{-1}$ although the maximum of $0.874 \mu \mathrm{g} \mathrm{I}^{-1}$ (Thursday at 22:00) was below the maximum observed in the 'high level' crude (Figure 3 a and b). Although there is some evidence of a diurnal flow pattern to both the 'low level' and 'high level' inlets with lower flows occurring from 06:00 - 10:00, there are no correlations between flows and the concentration of TBT.

\subsubsection{Removal of Tributyltin in Primary Sedimentation}

The concentration of TBT in the crude sewage increased from $0.164{\mu \mathrm{gl}^{-1}}^{-1}$ to $0.175 \mu \mathrm{g} \mathrm{I}^{-1}$ due to the incorporation of return flows (BAFF and RGF backwashes) (Figure 1) prior to primary sedimentation. Following primary sedimentation in the 'high level' stream, concentrations of TBT in the settled sewage had decreased to $0.072 \mu \mathrm{gl}^{-1}$. The removal of TBT from the 'high level' crude across the primary tanks was $56 \%$, and when compared to the removal of suspended solids (55\%) would indicate that TBT associated with particulate matter was being removed by settling. Statistical analysis of the 'high level' flows shown in Figure 4 indicated a significant difference between the concentrations of TBT observed following primary treatment at this tertiary treatment works (Kruskal-Wallis test, $p=<0.05$ ). 
Table 1. Total suspended solids, BOD and TBT concentrations and mass balance of TBT through the tertiary treatment works. Measured values reported as means \pm standard deviation.

\begin{tabular}{|c|c|c|c|c|c|}
\hline Sample $(\mathrm{n}=25)$ & $\begin{array}{c}\text { TSS } \\
\mathrm{mg} \mathrm{I}^{-1}\end{array}$ & $\begin{array}{l}\text { BOD } \\
\mathrm{mg} \mathrm{I}^{-1}\end{array}$ & $\begin{array}{l}\text { TBT } \\
\mu g^{-1}\end{array}$ & $\begin{array}{l}\text { Flow } \\
\text { Ml d }^{-1}\end{array}$ & $\begin{array}{c}\text { TBT Flux } \\
\mathrm{g} \mathrm{d}^{-1}\end{array}$ \\
\hline HL crude & $209 \pm 73$ & $194 \pm 71$ & $0.164 \pm 0.30$ & $24.3 \pm 5$ & 4.0 \\
\hline HL crude + return & $217 \pm 96$ & $170 \pm 62$ & $0.175 \pm 0.36$ & $28.6 \pm 5$ & 5.0 \\
\hline HL settled & $94 \pm 19$ & $124 \pm 34$ & $0.072 \pm 0.09$ & $28.5 \pm 5$ & 2.1 \\
\hline LL crude + return & $581 \pm 460$ & $380 \pm 156$ & $0.211 \pm 0.22$ & $28.9 \pm 10$ & 6.6 \\
\hline LL settled & $154 \pm 65$ & $272 \pm 66$ & $0.075 \pm 0.13$ & $31.6 \pm 10$ & 2.3 \\
\hline BT settled & $49 \pm 16$ & $49 \pm 24$ & $0.076 \pm 0.07$ & $31.0 \pm 10$ & 2.3 \\
\hline Filter feed & $100 \pm 61$ & $128 \pm 36$ & $0.063 \pm 0.07$ & $59.3 \pm 14$ & 3.7 \\
\hline BAFF feed & $20 \pm 6.3$ & $9.5 \pm 2.4$ & $0.064 \pm 0.10$ & $57.5 \pm 14$ & 3.7 \\
\hline RGF feed & $15 \pm 6.3$ & $4.4 \pm 2.2$ & $0.040 \pm 0.07$ & $56.7 \pm 14$ & 2.3 \\
\hline Final effluent & $9.0 \pm 6.7$ & $3.1 \pm 1.7$ & $0.052 \pm 0.11$ & $53.2 \pm 14$ & 2.8 \\
\hline
\end{tabular}

HL, 'high level' sewer influent; LL, 'low level' sewer influent; return, return flows

The concentrations of TBT after primary sedimentation for the 'low level' crude sewage plus returns showed significant removal of TBT (Kruskal-Wallis, $p=<0.05$ ) reducing concentrations by $64 \%$ to an average of $0.075 \mu \mathrm{g} \mathrm{I}^{-1}$ (Figure 4). The removal efficiency of suspended solids in these low level primary tanks was $74 \%$ and was consistent with the behaviour observed in the 'high level' system confirming the relationship between the removal of solids and TBT.

\subsubsection{Removal of Tributyltin in Biological Treatment}

After the primary settling stage the 'low level' flow was treated in the high rate biological filter and underwent subsequent sedimentation (the biotower process). The biotower process reduced the high BOD load entering via the 'low level' sewer. Although the biotowers reduced the BOD concentration (272 $\mathrm{mg} \mathrm{l}^{-1}$ to $49 \mathrm{mg} \mathrm{l}^{-1}$ ) and suspended solids content (154 $\mathrm{mg} \mathrm{l}^{-1}$ to 49 
(a) 1.2
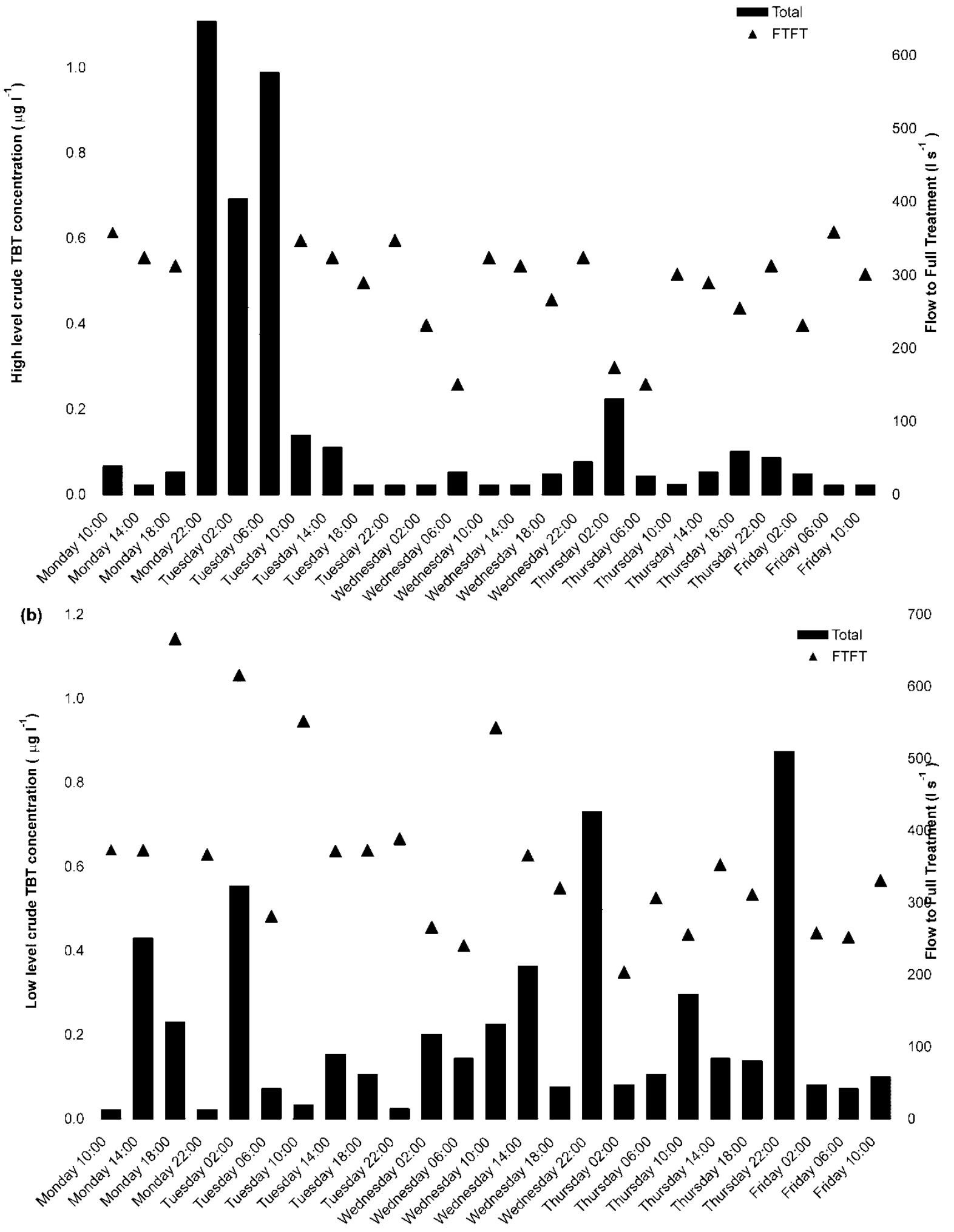

Figure 3. TBT concentrations ( $\mu \mathrm{g} \mathrm{I}^{-1}$ ) in (a) 'high level' and (b) 'low level' crude plus returns at the tertiary treatment works at four hourly intervals with flow to full treatment $\left(\mathrm{I} \mathrm{s}^{-1}\right)$. 
$\mathrm{mg} \mathrm{l}^{-1}$ ) (Table 1) there was no removal of TBT indicating that the TBT remaining after primary sedimentation was dissolved or associated with non-settleable solids.

After the biotower processes the 'low level' flow combined with the flow from the 'high level' primary tanks and this combined flow (55.2 $\mathrm{Ml} \mathrm{d}^{-1}$ referred to as filter feed) was sampled before the secondary biological trickling filters. Concentrations of TBT over the further filter processes are shown in Figure 4. The average concentration of TBT in the feed to the trickling filters was $0.063 \mu \mathrm{g} \mathrm{I}^{-1}$ and this remained effectively unchanged at $0.064 \mu \mathrm{g} \mathrm{I}^{-1}$ in the trickling filter effluent (Table 1). However, there was significant removal of BOD from 128 to $3.5 \mathrm{mg} \mathrm{l}^{-1}(97 \%)$ and SS from $100 \mathrm{mg} \mathrm{l}^{-1}$ to $20 \mathrm{mg} \mathrm{l}^{-1}(80 \%)$.

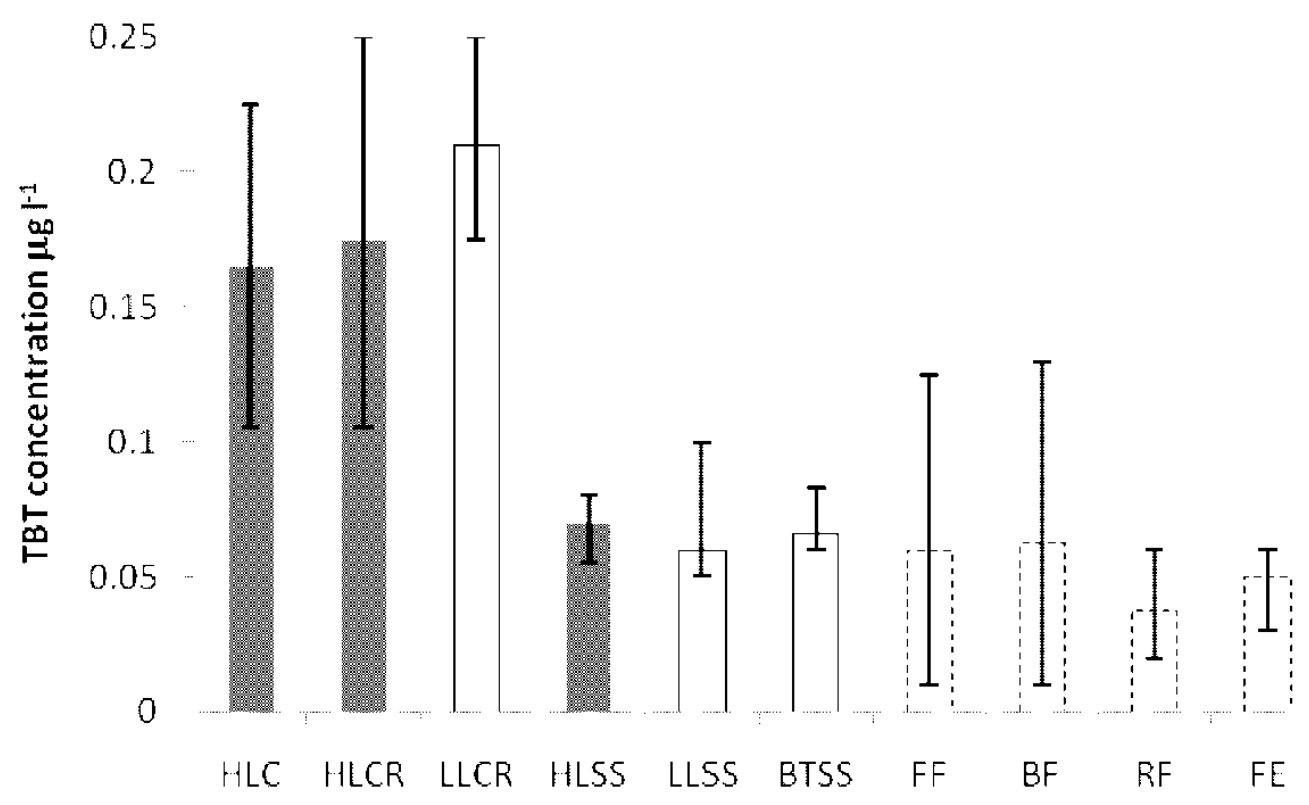

Key: High level flow $\square$; Low level flow $\square$; combined flows through further treatment :i

High level crude (HLC); High level crude plus returns (HLCR);Low level crude plus returns(LLCR); High level settled sewage (HLSS).; Low level settled sewage (LLSS); Bio-tower settled sewage (BTSS); Filter feed (FF); Biological aerated flooded filter feed (BF); Rapid gravity filter feed (RF) Final effluent (FE). Low level crude was not measured as it was not accessible.

Figure 4. Average concentrations of TBT across the 'high level' and 'low level' primary system and across the combined secondary and tertiary systems 


\subsubsection{Removal of Tributyltin in Tertiary Treatment}

Following the trickling filter the effluent was subject to tertiary treatment processes consisting of BAFFs and RGFs. There was limited further removal of BOD across these tertiary processes from $9.5 \mathrm{mg} \mathrm{l}^{-1}$ in the BAFF feed to $4.3 \mathrm{mg} \mathrm{l}^{-1}$ in the final effluent, ammonia was reduced from 4.6 to $0.7 \mathrm{mg} \mathrm{l}^{-1}$ by the BAFFs and SS decreased from 20 to $15 \mathrm{mg} \mathrm{l}^{-1}$ over the BAFFs and to 9 $\mathrm{mg} \mathrm{l}^{-1}$ after the RGFs (in the final effluent) (Table 1). Thus, the tertiary treatment processes were working effectively as designed. However, there was no statistically significant removal of TBT in these processes. The concentration in the feed to the BAFFs was $0.064 \mathrm{\mu g} \mathrm{I}^{-1}$ and was 0.052 $\mu \mathrm{g} \mathrm{I}^{-1}$ in the final effluent.

\subsubsection{Mass Balance and Fate of TBT}

Flow to the works was closely balanced between the 'high level' (46\%) and 'low level' (54\%) inlets. The total input of TBT averaged $9.7 \mathrm{~g} \mathrm{~d}^{-1}$ during the sampling week (Figure 1) with a slightly greater input ( $59 \%$ of the total) in the 'low level'. Removal during primary treatment was effective with the 'high level' tanks removing 58\% of their TBT load and the 'low level' tanks removing $65 \%$ of their TBT load, indicating around $60 \%$ of TBT was associated with settleable solids.

There was no removal of TBT in the biotowers. Therefore, the mass balance analysis indicated that the daily flux of TBT to the trickling filters from the 'high level' primary tanks was $2.1 \mathrm{~g} \mathrm{~d}^{-1}$ and from the 'low level' settled sewage, following treatment in the biotowers, $2.3 \mathrm{~g} \mathrm{~d}^{-1}$ resulting in a load of $4.4 \mathrm{~g} \mathrm{~d}^{-1}$ in the filter feed (Figure 1). The load calculated from the average concentration and flow at this sampling point was $3.7 \mathrm{~g} \mathrm{~d}^{-1}$ which is deemed to be a good match. 
The mass fluxes of TBT in the return humus sludge, BAFF and RGF backwashes are shown in Figure 1. Taken individually, these values do not balance the flux measured across the three processes, however, the total average daily flux in the humus sludge and backwash liquors of $1.4 \mathrm{~g} \mathrm{~d}^{-1}$ is a relatively close fit with calculated removal of $0.7 \mathrm{~g} \mathrm{~d}^{-1}$ of TBT over these three unit processes.

The mass balance approach allows for the determination of the removal rate across the whole works, which was $71 \%$, and this predominantly occurred in the primary system through settlement. Although it is not possible to give any statistically valid values for removal of TBT between the filter feed and subsequent treatment on the BAFF and RGF, there was on average $20 \%$ removal of the load of TBT between the trickling filters $\left(3.5 \mathrm{~g} \mathrm{~d}^{-1}\right)$ and the final effluent $(2.8$ $\left.\mathrm{g} \mathrm{d}^{-1}\right)$. Overall, however, the trickling filters, BAFF and RGF removed $0.7 \mathrm{~g} \mathrm{~d}^{-1}$, or $10 \%$ of the total removal of TBT $\left(6.8 \mathrm{~g} \mathrm{~d}^{-1}\right)$, highlighting the significance of the primary sedimentation processes in accounting for TBT removal at the tertiary treatment works.

\subsection{The Fate of Tributyltin in the Conventional Trickling Filter Treatment Works}

The TBT concentrations entering the works averaged $0.692 \mu \mathrm{gl}^{-1}$ (Table 2). A maximum concentration of $3.205 \mu \mathrm{g} \mathrm{I}^{-1}$ was observed on Thursday at 14:00. Overall, there appeared to be a diurnal trend in the flows observed (Figure 5), however, this appears to be uncorrelated to the concentration of TBT in the crude sewage. The other inlet flow to the conventional trickling filter works was a brewery wastewater $\left(4.5 \mathrm{Ml} \mathrm{d}^{-1}\right.$ ) with a TBT concentration of $0.307 \mu \mathrm{g} \mathrm{I}^{-1}$ (Table 2). The brewery flow contributed to $2.7 \%$ of the total load of TBT to the works and did not undergo primary treatment. 
Table 2. Total suspended solids, BOD and TBT concentrations and mass balance of TBT through the conventional trickling filter works. Measured values reported as means \pm standard deviation.

\begin{tabular}{lccccc}
\hline Sample $(\mathrm{n}=25)$ & $\begin{array}{c}\mathrm{TSS} \\
\mathrm{mg} \mathrm{l}^{-1}\end{array}$ & $\begin{array}{c}\mathrm{BOD} \\
\mathrm{mg} \mathrm{l}^{-1}\end{array}$ & $\begin{array}{c}\text { TBT } \\
\mathrm{mg} \mathrm{l}^{-1}\end{array}$ & $\begin{array}{c}\text { Flow } \\
\mathrm{Ml} \mathrm{d}^{-1}\end{array}$ & $\begin{array}{c}\text { TBT Flux } \\
\mathrm{g} \mathrm{d}^{-1}\end{array}$ \\
\hline Municipal crude & $223 \pm 121$ & $200 \pm 94$ & $0.692 \pm 0.79$ & $71 \pm 35$ & 49.4 \\
Municipal crude +return & $367 \pm 129$ & $228 \pm 109$ & $0.325 \pm 0.29$ & $73 \pm 35$ & 23.9 \\
Municipal settled & $128 \pm 38$ & $154 \pm 59$ & $0.663 \pm 0.61$ & $73 \pm 35$ & 48.5 \\
& & & & & \\
Brewery crude & $336 \pm 270$ & $1977 \pm 2888$ & $0.307 \pm 0.38$ & $4.5 \pm 0.3$ & 1.4 \\
Brewery crude + return & - & - & - & 5.2 & 1.6 \\
Brewery settled & $113 \pm 56$ & $232 \pm 78$ & $0.041 \pm 0.023$ & $5.0 \pm 0.3$ & 0.2 \\
& & & & & \\
Filter feed & - & - & - & 90 & 49.1 \\
Filter feed + recirc. & 30 & 12 & 0.035 & 90 & 3.1 \\
Final effluent & $30 \pm 11$ & $12 \pm 7$ & $0.035 \pm 0.07$ & $77 \pm 35$ & 2.7 \\
\hline
\end{tabular}

return; return flows; recirc., the recirculation of final effluent over the trickling filters

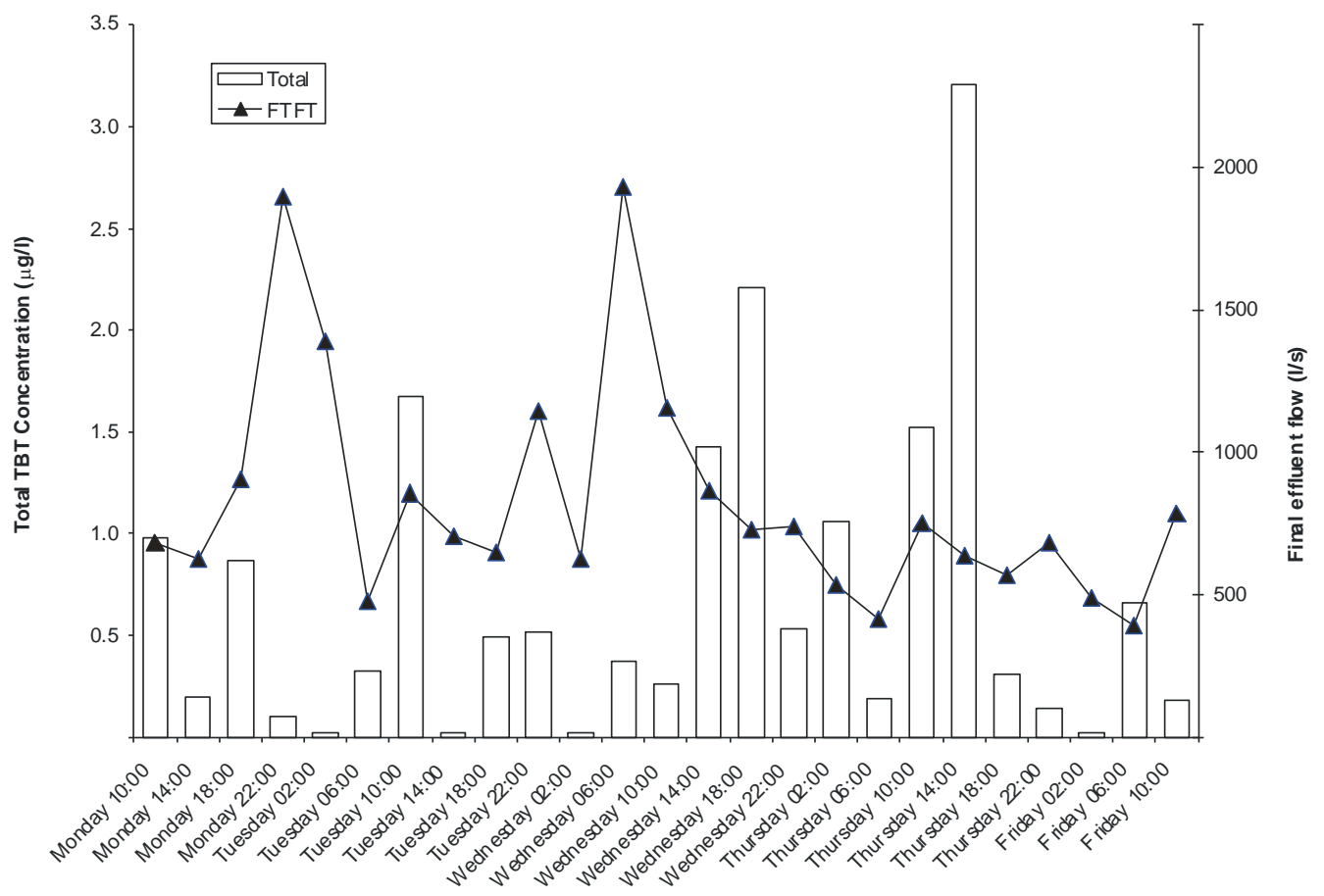

Figure 5. Total TBT concentrations $\left(\mu \mathrm{g} \mathrm{I}^{-1}\right)$ in crude sewage at the conventional trickling filter works at four hourly sample points plotted with final effluent flow $\left(\mathrm{I} \mathrm{s}^{-1}\right)$. 


\subsubsection{Removal of Tributyltin in Primary Sedimentation}

The average concentration of TBT entering primary treatment with returns was $0.325 \mu \mathrm{g} \mathrm{I}^{-1}$ which was below the average crude concentration of $0.692 \mu \mathrm{g} \mathrm{I}^{-1}$ and may have been the consequence of analytical interference, as samples with return flows were visually dirtier and more difficult to extract than those of crude and settled sewage. The settled sewage concentration was $0.663 \mu \mathrm{g} \mathrm{I}^{-1}$ (Table 2). Statistical analysis of the non-normally distributed data was undertaken by the non-parametric Kruskal-Wallis test on the rank scores followed by a Dunnett's test to determine any significant differences from the main flow sampling points. The analysis indicated no significant differences (at the $99 \%$ significance level) between the TBT concentrations observed in the crude, crude plus returns and settled sewage, indicating that there was no significant removal of TBT across the primary tanks (Figure 6). Lack of removal in the primary tanks would indicate that TBT coming into the conventional trickling filter works was not associated with settleable solids and analysis of the solids collected indicated that only between $3-11 \%$ of TBT was present on the suspended solids. This was a different situation to the other works, where around $60 \%$ of TBT was associated with the settleable solids.

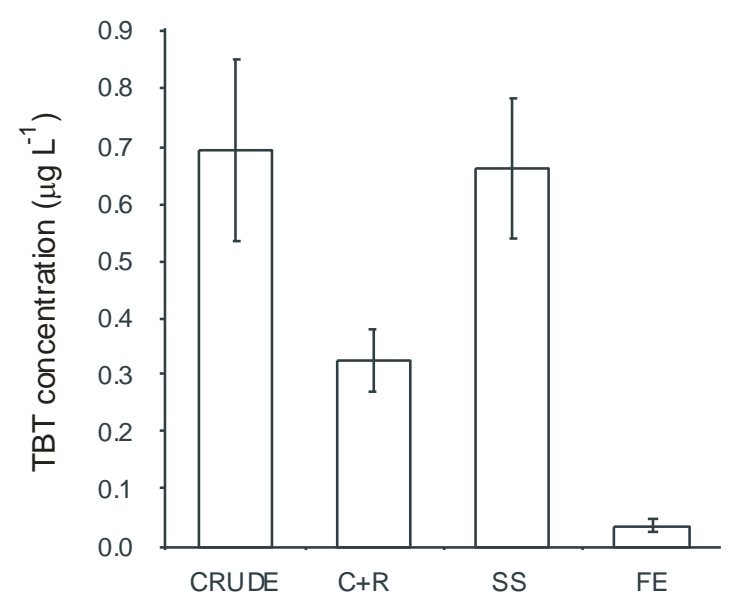

Key: Crude plus returns $(\mathrm{C}+\mathrm{R})$; settled sewage (SS); final effluent (FE)

Figure 6. Average concentrations of TBT across the conventional trickling filter works 


\subsubsection{Removal of Tributyltin in Biological Treatment}

The brewery influent was directly treated in high rate biological filters (biotowers) without prior primary sedimentation. The biotowers effectively removed BOD and TSS. The BOD concentration entering the biotowers was $1977 \mathrm{mg} \mathrm{l}^{-1}$ and $88 \%$ was removed over this process. Correspondingly, $66 \%$ of the TSS was removed from an initial concentration $336 \mathrm{mg} \mathrm{l}^{-1}$. The TBT concentration was reduced from $0.307 \mu \mathrm{gl}^{-1}$ to $0.041 \mu \mathrm{g} \mathrm{I}^{-1}$ through the biotowers which equates to an overall removal of $87 \%$ of which an estimated $63 \%$ was a result of biodegradation as the balance of TBT removed was not found in the sludge from the biotowers (Brewery Humus flux, Figure 2). If biodegradation is occurring in these biotowers, it will most probably be a result of a two stage process, firstly uptake by the biomass, and secondly degradation. With a fixed film biological process, it is not possible to determine the age of the biomass and hence it is not possible to calculate the rate of degradation or half life of the TBT.

These high rate biological filters performed differently to those at the tertiary WWTW, which may have been the result of the relatively high temperature $\left(35\right.$ to $\left.40^{\circ} \mathrm{C}\right)$ of the influent from the brewery (compared to a more usual sewage temperature of $19^{\circ} \mathrm{C}$ in the low level crude at the tertiary WWTW), and operated at a lower hydraulic loading of $0.61 \mathrm{~m} / \mathrm{h}$ compared to $1.91 \mathrm{~m} / \mathrm{h}$ at the tertiary WWTW. Extraction fans to remove foul air from the high rate filters were also used at the conventional plant and these may have increased aeration, which was otherwise natural at both sites. The media content (structured plastic) of the two high rate filters, and other operational parameters (they were not backwashed) were similar.

The concentration of TBT in the settled sewage (primary tank effluent) flowing to the trickling filters was $0.663 \mu \mathrm{g} \mathrm{I}^{-1}$. The primary tank effluent combined with the flow from the brewery treatment stream as it entered the trickling filters, and sampling of the combined flow was not possible. However, TBT the brewery stream would have had little impact on the TBT 
concentration, as it contributed around $6 \%$ of flow and $3 \%$ of the TBT flux through the WWTW. An input to the trickling filters of $0.663 \mu \mathrm{g} \mathrm{I}^{-1}$ and a final effluent concentration of $0.035 \mu \mathrm{g} \mathrm{I}^{-1}$, indicates a $94 \%$ removal of TBT during biological secondary treatment. If TBT was removed by adsorption over the trickling filter it would accumulate in the humus sludge. The humus sludge was subsequently returned to the main flow and co-settled in the primary tanks. Hence TBT would also be expected to be present in the co-settled sludge. This is examined further in the following mass balance section below.

\subsubsection{Mass Balance and Fate of TBT}

There was $49.4 \mathrm{~g} \mathrm{~d}^{-1}$ of TBT entering the conventional trickling filter works from the main flow (Crude stream, Figure 2) and although this showed a decrease before primary treatment with the addition of return flows $\left(23.9 \mathrm{~g} \mathrm{~d}^{-1}\right)$ the flux in both settled sewage and subsequent filter feed samples (which included addition of the brewery flow) indicated that no significant removal of TBT occurred during primary sedimentation (Figure 2). This was in marked contrast to the removal in the primary stages in the tertiary treatment works which was over $58 \%$.

The mass load to the trickling filters was $49.1 \mathrm{~g} \mathrm{~d}^{-1}$. The calculated removal in $\mathrm{g} \mathrm{d}^{-1}$ of TBT over the trickling filters was $46.4 \mathrm{~g} \mathrm{~d}^{-1}$ (Figure 2) which would have been expected to be found in the humus return flow if the TBT was removed by adsorption alone. However, the flux observed in the humus sludge, calculated by concentration $\left(0.602 \mathrm{\mu g} \mathrm{l}^{-1}\right)$ and recorded flow $\left(648 \mathrm{~m}^{3} \mathrm{~d}^{-1}\right)$, was $0.4 \mathrm{~g} \mathrm{~d}^{-1}$ which indicated that TBT was not accumulating in the sludge. This was also confirmed by the low flux observed in the co-settled sludge of $1.8 \mathrm{~g} \mathrm{~d}^{-1}$ which contained the humus sludge. It would therefore appear that the TBT was degrading during the biological process, which, like the biotowers, was a fixed film process and once TBT has been adsorbed to the biomass, the 
actual degradation rate is not known, although it was removed from the flow during the time taken to pass through the filter.

The mass flux across the whole conventional trickling filter works indicated that the overall removal of TBT was $94.5 \%$ and that $93.6 \%$ removal was observed to be due to the trickling filter. This is contrary to observations of the tertiary treatment works where the overall removal was $71 \%$ and this was predominantly due to removal in the primary treatment processes. Both WWTW also had high rate biological filters at different stages in the process flow. At the conventional WWTW, biodegradation was apparently occurring in this process as well, however, this was not observed at the tertiary treatment works.

\section{Discussion}

Tributylin is inclined to be resistant to both chemical and biological degradation and to preferentially associate with solids (Fent and Muller 1991; Voulvoulis et al. 2004). In Table 3 the data from the published studies of the fate and behaviour of these compounds in full-scale wastewater treatment works, including works examined in this study, are tabulated. It can be seen that there are some significant differences in their behaviour at these sites. Removals during the primary stage of treatment are solely dependent on association with settleable solids. It is possible that the poor removal during primary sedimentation at the conventional percolation filter works in this study could be explained by the solid liquid phase distribution. There could have been a significant industrial source of TBT (e.g. through its use as a plasticiser) which was predominantly in the soluble phase thus removal during primary sedimentation would have been reduced due to the non-settleable nature of the soluble TBT. Since the influent crude sewage concentration of TBT was very much higher $\left(0.692 \mu \mathrm{g} \mathrm{I}^{-1}\right)$ at this conventional trickling filter works compared to the tertiary works $\left(0.164 \mu \mathrm{g} \mathrm{I}^{-1}\right.$ 'high level' and $0.211 \mu \mathrm{g} \mathrm{I}^{-1}$ 'low level'), it 
Table 3. Percentage removals of suspended solids (SS) organotin compounds (monobutyltin, MBT; dibutyltin, BDT and TBT) during wastewater treatment (adapted from Voulvoulis et al. 2004).

\begin{tabular}{|c|c|c|c|c|c|c|c|}
\hline & \multicolumn{3}{|c|}{ Fent and Muller (1991) } & \multicolumn{4}{|c|}{ Voulvoulis et al (2004) } \\
\hline Process & $\begin{array}{ll}\text { SS } & \text { MBT }\end{array}$ & DBT & TBT & SS & MBT & DBT & TBT \\
\hline Primary & 62 & 80 & 66 & 64 & 82 & 87 & 81 \\
\hline Secondary & 30 & 70 & 64 & 73 & 83 & 87 & 71 \\
\hline Tertiary & N/D & 79 & 91 & $N / A$ & $N / A$ & $\mathrm{~N} / \mathrm{A}$ & $\mathrm{N} / \mathrm{A}$ \\
\hline \multirow[t]{2}{*}{ Total } & 90 & 98 & 99 & 82 & 95 & 84 & 86 \\
\hline & \multicolumn{3}{|c|}{ Donard et al. (1993) } & \multicolumn{4}{|c|}{ Chau et al. (1992) } \\
\hline Process & SS $\quad$ MBT & DBT & TBT & SS & MBT & DBT & TBT \\
\hline Primary & 46 & 17 & & & & & \\
\hline Secondary & 14 & 90 & & & & & \\
\hline Tertiary & & & & & & & \\
\hline \multirow[t]{2}{*}{ Total } & & & & & 39 & 100 & 100 \\
\hline & \multicolumn{3}{|c|}{ Bancon-Montigny et al. (2000) } & \multicolumn{4}{|c|}{ Stasinakis et al. (2005) } \\
\hline $\begin{array}{l}\text { Process } \\
\text { Primary }\end{array}$ & SS $\quad$ MBT & DBT & TBT & & MBT & DBT & TBT \\
\hline $\begin{array}{l}\text { Secondary } \\
\text { Tertiary }\end{array}$ & & & & $\left(\mathrm{BAS}^{*}\right)$ & 49.7 & 90.4 & 99.7 \\
\hline Total & 47 & 79 & 84 & & & & \\
\hline
\end{tabular}

Treatment works from this present study

\begin{tabular}{|c|c|c|c|c|c|c|c|}
\hline \multicolumn{4}{|c|}{ Tertiary WWTW } & \multicolumn{4}{|c|}{ Conventional WWTW } \\
\hline Process & SS $\quad$ MBT & DBT & TBT & SS & MBT & DBT & TBT \\
\hline Primary & 65 & & 62 & 66 & & & 7 \\
\hline Secondary & 80 & & $-2 \%$ & 77 & & & 95 \\
\hline Tertiary & 55 & & 19 & - & & & - \\
\hline Total & 96 & & 68 & 87 & & & 95 \\
\hline
\end{tabular}

Key: Where data are missing, theyr were not reported in the studies

${ }^{*}$ BAS $=$ Batch activated sludge, laboratory scale with synthetic sewage

would suggest that there was a significant industrial source for this extra TBT. It is also possible that during the period of this study the TBT species were subject to repartitioning into the soluble phase. During the sampling period the catchment was subject to several short but intensive storm events which raised the hydraulic load rapidly and significantly. These storm events could have also in turn re-partitioned TBT into the soluble phase. It has been established 
that the sorption of TBT compounds to sediments high in organic matter is a fast and reversible process (Berg et al. 2001). This is in contrast with other organic micropollutants such as polynuclear aromatic hydrocarbons which are tightly bound to carbonaceous components of the sediments and are not easily removed (Gustafesson et al. 1997). The impact of storms on the resuspension and solubilisation of contaminants has been clearly recognized by Berg et al. (2001) as a factor in their subsequent bioavailability and biodegradation.

In the biological stage of the conventional works in this study removal of TBT was greater than $90 \%$. Whilst this may appear to be at odds with the observations of Fent and Mueller (1991) and Voulvoulis et al. (2004), the other studies, whilst less detailed (Table 3), all suggest that biodegradation of TBT (and other organotins) does occur. It is possible that the solubility of TBT that reduced removal during primary sedimentation was responsible for facilitating uptake and subsequent biodegradation during secondary biological treatment in the conventional trickling filter works. In addition, the concentration of TBT in settled sewage at this works was higher than in the tertiary treatment works or those studied by Fent and Mueller (1991) or Voulvoulis et al. (2004). It would appear that if the influent concentration was higher it is also possible that the soluble, biologically available, concentration was higher.

In marine and estuarine waters and sediments, half lives of TBT are measured in years, for example 2.1 years for TBT, 1.9 years for DBT and 1.1 years for MBT (Sarradin et al. 1995). These matrices are very low in active bacteria. Nevertheless, as in wastewater treatment, much shorter half live values have been observed in organic rich aquatic environments, most probably reflecting the higher concentrations of bacteria in these environments. For example, the half live of TBT in the highly fertilised "Beaver Pond" was only 28 days, whilst in the less enriched "Crystal Lake" it was 78 days (Landmeyer et al. 2004). The critical role of bacteria the biodegradation removal mechanism appears to be clearly established by the studies of Vossler et al. (1986) using azide to eliminate biological activity and with it TBT breakdown. Not only do 
high concentrations of bacteria appear to enhance TBT breakdown but the presence of soluble organic matter, which is abundant in sewage also appears to enhance removal (Kawai et al. 1998). Utilising a laboratory scale batch activated sludge process for biological wastewater treatment supplied with synthetic sewage, Stasinakis et al. (2005), observed half lives for TBT, DBT and MBT of 1.4, 3.6 and 9.8 days respectively. Although this system of treatment was directly comparable to that studied by Voulvoulis et al. (2004), in the later full-scale studies, the influent organotin concentrations were much lower and this could have been a significant factor in the observed behaviour. From the results reported here, for the removal of TBT in a fixed film, trickling filter process, it was not possible to calculate the degradation rate of the TBT, but it was removed from the wastewater as it passed over the biological film, and was subsequently degraded before the film sloughed away from the media to be removed as humus sludge. It therefore appears that the biodegradation of TBT does occur during biological wastewater treatment, and is probably dependent on complex biochemical metabolism (Graham and Curtis 2003) and particularly dependent on the ratio between readily biodegrable organic matter (BOD) and the concentration of the recalcitrant contaminant (McAdam et al. 2011). Therefore, further understanding of the potential of biological processes would be of benefit in developing removal strategies for hazardous substances such as TBT from wastewaters (Jones et al. 2007b).

\section{Conclusions}

1. The removal of TBT showed a significant correlation with suspended solids removal at one works, however at the other site, this relationship was not present.

2. At the conventional treatment works, degradation of TBT was observed in two fixed film biological processes, however, due to the nature of the growth in these systems, no inference on degradation rates could be made. 
3. Differences in TBT speciation (dissolved or associated with solids in the sewage) at these two wastewater works resulted in different removal mechanisms.

4. Further understanding of the organisms responsible for, and the mechanisms of biodegradation may allow for more effective biological treatment processes for the removal of hazardous chemicals.

Acknowledgements The authors are grateful to United Utilities PLC for funding the work and for the permission to publish the results.

\section{References}

Alzieu, C., Sanjuan, J., Michel, P., Borel, M., Dreno, J.P. (1989). Monitoring and assessment of butyltins in Atlantic coastal waters. Marine Pollution Bulletin, 20, 22-26.

Bacon-Montigny, Ch., Lespes, G., Potin-Gautier, M. (2000). Improved routine speciation of organotin compounds in environmental samples by pulsed flame photometric detection. Journal of Chromatography A, 896, 149-158.

Bedding, N.D., McIntyre, A.E., Perry, R., Lester, J.N. (1982). Organic contaminants in the aquatic environment. I. sources and occurrence. Science of the Total Environment, 25, 143-167.

Berg, M. Arnold, C.G., Muller, S.R., Muhlemann, J., Schwarzenbach, R.P. (2001). Sorption and desorption behavior of organotin compounds in sediment - pore water systems. Environmental Science and Technology, 35, $3151-3157$.

Chau, Y.K., Zhang, S., Maguire, J. (1992). Occurrence of butyltin species in sewage and sludge in Canada. Science of the Total Environment, 121, 271-281.

Clark, E.A., Sterritt, R.M., Lester, J.N. (1988). The fate of tributyltin in the aquatic environment: an overview. Environmental Science and Technology, 22, 600-604.

Dodds, E. C., Goldberg, L., Lawson, W., Robinson, R. (1938). Oestrogenic activity of certain synthetic compounds. Nature, 141, 247.

Donard, O.F.X., Quevauviller, P. Bruchet, A. (1993). Tin and organotin speciation during wastewater and sludge treatment process. Water Research, 27, 1085-1089. 
Dowson, P.H., Bubb, J.M., Lester, J.N. (1993a). A study of the partitioning and sorptive behaviour of butyltins in the aquatic environment. Applied Organometallic Chemistry, 7, 623633.

Dowson, P.H., Bubb, J.M., Lester, J.N. (1993b). Temporal distribution of organotins in the aquatic environment five years after the 1987 UK retail ban on TBT based antifouling paints. Marine Pollution Bulletin, 26, 487-494.

Dowson, P.H., Bubb, J.M., Williams, T.P., Lester, J.N. (1993c). Degradation of tributyltin in freshwater and estuarine marina sediments. Water Science and Technology, 28, 133-137.

Dowson, P.H., Bubb, J.M., Lester, J.N. (1994). The effectivenss of the 1987 retail ban on TBT based antifouling paints in reducing butyltin concentrations in East Anglia, UK. Chemosphere, 28, 905-910.

Fent, K., Muller, M.D. (1991). Occurrence of Organotins in Municipal Wastewater and sewage sludge and behaviour in a treatment plant. Environmental Science and Technology, 25, 489493.

Graham, D.W., Curtis, T.P. (2003). Ecological theory and bioremediation. In: Head,I.M., Singleton, I., Milner, M.G. (Eds.), Bioremediation - A Critical Review. Horizon Scientific Press, Norwich, UK.

Gustafsson, Ö., Haghseta, F., Chan, C., Macfarlane, J., Gschwend, P.M. (1997). Quantification of the dilute sedimentary soot phase: Implications for PAH speciation and bioavailability. Environmental Science and Technology, 31, 203-209.

Hoch, M. (2001). Organotin compounds in the environment - An overview. Applied Geochemistry, 16, 719-743.

Jones, O.A.H., Voulvoulis, N., Lester, J.N. (2007a). The occurrence and removal of selected pharmaceutical compounds in an English sewage treatment works utilizing activated sludge treatment. Environmental Pollution, 145, 738-744.

Jones, O.A.H., Green, P., Voulvoulis, N., Lester, J.N. (2007b). Questioning the excessive use of advanced treatment to remove organic micropollutants from wastewater. Environmental Science and Technolology, 41, 5085-5089.

Kawai, S. Kurokawa, Y., Harino, H., Fukushima, M. (1998). Degradation of tributyltin by a bacterial strain isolated from polluted river water. Environmental Pollution, 102, 259-263. 
Landmeyer, J.E., Tanner, T.L., Watt, B.E. (2004). Biotransformation of tributyltin to tin freshwater river-bed sediments contaminated by an organotin release. Environmental Science and Technology, 38, 4106-4112.

Maguire, R.J. (1987). Review: Environmental aspects of tributyltin. Applied Organometallic Chemistry 1, 475-498.

McAdam, E., Bagnall, J., Soares, A., Koh, Y.K.K., Chiu, T.Y., Scrimshaw, M.D., Lester, J., Cartmell, E. (2011). Fate of alkylphenolic compounds during activated sludge treatment: Impact of loading and organic composition. Environmental Science and Technology, 45, 248-254.

Plagellat, C. Kupper, T., de Alencastro, L.F., Grandjean, D., Tarradellas, J. (2004). Biocides in sewage sludge: Quantitative determination in some Swiss wastewater treatment plants. Bulletin of Environmental Contamination and Toxicology, 73, 794-801.

Sarradin, P-M, Lapaquillerie, Y., Astruc, A., Latouche, C., Astruc, M. (1995). Long term behaviour and degradation kinetics of tributyltin in a marine sediment. Science of the Total Environment, 170, 59-70.

Seligman, P.F., Valkirs, A.O., Lee, R.F. (1986). Degradation of tributyltin in San Diego Bay, California, waters. Environmental Science and Technology, 20, 1229-1235.

Seligman, P.F., Grouhoud, J.G., Valkirs, A.D., Stang, P.M., Fransham, R., Stallard, M.O., Davidson, B., Lee, R.F. (1989). Distribution and fate of Tributyltin in the United States marine environment. Applied Organometallic Chemistry, 3, 31-47.

Stasinakis, A.S., Thomaidis, N.S., Nikolaou, A., Kantifes, A. (2005). Aerobic biodegradation of organotin compounds in activated sludge batch reactors. Environmental Pollution, 134, 431438.

Vossler, T.L., Maclas, E. (1986). Contribution of fine particle sulfates to light scattering in St. Louis summer aerosol. Environmental Science and Technology, 20, 1235-1243.

Voulvoulis, N., Scrimshaw, M.D., Lester, J.N. (2004). Removal of organotins during sewage treatment: a case study. Environmental Technology, 25, 733-740. 